\title{
Cell Phone Detection Techniques
}
RM Pratt
RW Slaugh
KJ Bunch
MS Good
DJ Puzycki
DL McMakin

October 2007

\section{Pacific Northwest}




\title{
DISCLAIMER
}

This report was prepared as an account of work sponsored by an agency of the United States Government. Neither the United States Government nor any agency thereof, nor Battelle Memorial Institute, nor any of their employees, makes any warranty, express or implied, or assumes any legal liability or responsibility for the accuracy, completeness, or usefulness of any information, apparatus, product, or process disclosed, or represents that its use would not infringe privately owned rights. Reference herein to any specific commercial product, process, or service by trade name, trademark, manufacturer, or otherwise does not necessarily constitute or imply its endorsement, recommendation, or favoring by the United States Government or any agency thereof, or Battelle Memorial Institute. The views and opinions of authors expressed herein do not necessarily state or reflect those of the United States Government or any agency thereof.

\author{
PACIFIC NORTHWEST NATIONAL LABORATORY \\ operated by \\ BATTELLE \\ for the \\ UNITED STATES DEPARTMENT OF ENERGY \\ under Contract DE-AC05-76RL01830
}

Printed in the United States of America
Available to DOE and DOE contractors from the Office of Scientific and Technical Information,
P.O. Box 62, Oak Ridge, TN 37831-0062;
ph: (865) 576-8401
fax: $(865)$ 576-5728
email: reports@adonis.osti.gov

\begin{abstract}
Available to the public from the National Technical Information Service, U.S. Department of Commerce, 5285 Port Royal Rd., Springfield, VA 22161 ph: (800) 553-6847 fax: $(703) 605-6900$ email: orders@ntis.fedworld.gov online ordering: http://www.ntis.gov/ordering.htm
\end{abstract}

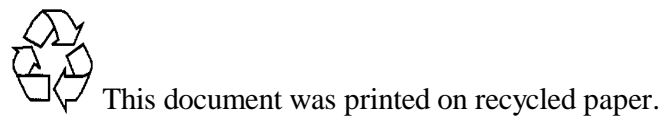




\section{Cell Phone Detection Techniques}

Rick Pratt, Kyle Bunch, Dave Puczyki, Ryan Slaugh, Morris Good, and Doug McMakin

October 2007

Pacific Northwest National Laboratory

Operated by Battelle

for the U.S. Department of Energy

under Contract DE-AC05-76RL01830

The material contained herein is submitted for information purposes and is not binding on the Pacific Northwest National Laboratory, or the U.S. Department of Energy. Binding commitments can only be made by the submission of a formal proposal which sets forth a specific Statement of Work, estimated cost, and contract documents, and which is signed by a Pacific Northwest National Laboratory Contracting Officer and transmitted by the U.S. Department of Energy. 


\section{Cellular Telephone Detection Techniques}

\section{Summary}

A team composed of Rick Pratt, Dave Puczyki, Kyle Bunch, Ryan Slaugh, Morris Good, and Doug McMakin teamed together to attempt to exploit cellular telephone features and detect if a person was carrying a cellular telephone into a Limited Area. The cell phone's electromagnetic properties were measured, analyzed, and tested in over 10 different ways to determine if an exploitable signature exists. The method that appears to have the most potential for success without adding an external "tag" is to measure the RF spectrum, not in the cell phone band, but between 240 and $400 \mathrm{MHz}$. Figures 1- 7 show the detected signal levels from cell phones from three different manufacturers.

\section{Recommended Path Forward}

We recommend continuing the development of the cellular phone detector using the RF spectrum measurement approach. This approach listens for spurious emissions resulting from the cellular phone when it is either waiting for a call or transmitting. This approach has several advantages including:

1. The detection method is completely passive - it does not require using an external signal to detect the cellular telephone.

2. The band of frequencies identified to detect a wide variety cellular telephones is limited. Since the RF section of a cellular phone must produce a signal within the allocated FCC frequency spectrum, it is likely that manufacturers would not redesign the RF section. Further, a limited number of chip sets used to generate the RF are likely to be used by most manufacturers. Thus, spurious emissions are likely to occur at common frequencies among different models. Further, the fact that the channel frequencies are fixed dictates the oscillator frequency and the multiplier factors in order to generate these frequencies.

3. The system would be flexible to detect more than cell phones. Most active electronics radiates some spurious emissions, and a system could be built to select for particular RF bands. Further, a system could be made to adapt to changes in technology.

4. The system should be useful for many future generations of cellular phones. Manufacturers are required to satisfy FCC minimum spurious power emissions. However, no requirements exist to reduce these emissions to zero, even if this were possible. Because shielding is costly, it is likely manufacturers will continue to design to this minimum requirement and not below. Thus, all cellular phones are likely to have some level of detectable emissions even as technology advances.

5. The system has the potential to detect a cellular phone even when it is turned off. However, this possibility is unlikely. A cellular telephone has some minimal electronics active even when turned off. For example, it is known that a cellular phone can be set to wake up at a particular time; thus, at minimum, a clock must be running. If this electronics produces spurious emissions, it is possible to detect the phone. Additional testing is necessary to evaluate this option to date. 
At this point, we have demonstrated that spurious emissions can be detected from several models of cellular phones in the frequency range from 240-400 $\mathrm{MHz}$. We have not performed a thorough analysis of these emissions, nor a thorough study of emissions from different model phones. Further, we have more advanced equipment that can more thoroughly analyze cellular phone emissions than what was available when this project began. Given the potential of this detection method, we propose the following path forward:

1. Perform a thorough spectrum analysis of several cellular phone models. We have a realtime spectrum analyzer that will allow us to perform analyses over a wider bandwidth. We will also be able to detect frequency "hopping" in order to better determine what frequency bands are likely to produce the best detection coverage. This effort will require some Labview programming in order to control the real-time spectrum analyzer. We can further analyze cellular phones when they are turned off to search for spurious emissions.

2. Determine the source of spurious emissions from cellular phones. We have not determined if the emissions we have detected are generated from the computer electronics (i.e., a computer clock chip) or from the RF chain of the phone. We have several cellular phones that have been donated to us that we can carefully disassemble and probe to determine the source of these emissions.

3. Determine the chip sets typically used in cellular phones and the likely spurious emissions generated from these chip sets. We can test a large number of cellular phone models, but we cannot test them all. Thus, if we can determine common electronics among different models, we may be able to reasonably extrapolate as to the likely success rate of this detection method for most models.

4. Perform detection experiments within the most promising bands. Our experiment was performed in a metal box with an antenna close to the cellular phones. In this way, we were most likely to find spurious emissions from each phone. It will be necessary to determine bounds on standoff detection from these emissions. Fortunately, portal detection will require detection distances less than a few meters.

5. Determine hardware requirements for a detection system. A hardware system will most likely have to scan over a frequency range using a sensitive detector with a narrow band filter. Sensitivity requirements, bandwidth requirements, and so forth, will allow us to estimate hardware costs and system feasibility.

\section{Alternative Path Forward}

Another potential path forward is also proposed, but will require additional testing to validate. This method involves sending a short RF pulse (within the cellular phone band) and listen for a two responses - the first response is from any RF reflecting material and a second response (slightly delayed) from the cellular phone filters used on all phones. This approach has the potential to detect cellular phones whether they are ON or OFF or transmitting.

\section{Background}

Cell phones have become a very popular communication tool and have been used to surreptitiously gather sensitive information (Appendix A). The need to restrict these devices from areas containing protected information has become apparent and requirements have been mandated. These protection requirements have resulted in 100's of security infractions in the national laboratories each year. Savannah River, 
Los Alamos, and Oak Ridge have tested and begun installing a low-powered active RF tag called Rubee and a reader in a portal to perform this function. Each cell phone user must attach one of these tags to his cellular telephone. Sandia National Laboratory presented a technology for detecting cellular phones developed using their internal research and development funding. PNNL testing using a similar approach identified some weaknesses in the Sandia approach.

Bechtel-Nevada conducted an evaluation of a representative sample of commercial cellular telephone detectors in 2003. Sandia National Labs also conducted an evaluation of commercial cellular telephone detectors. There summary finding was that none of the commercial products was effective in detecting cell phones when they are turned off, or if they are turned on and a phone call is not in progress.

Testing Philosophy

Mobile phones are highly mobile communications devices that perform an array of functions ranging from that of a simple digital organizer to that of a low-end personal computer. Designed for mobility, they are compact in size, battery powered, and lightweight. Most cell phones have a basic set of comparable features and capabilities. They house a microprocessor, read only memory (ROM), random access memory (RAM), a radio module, a digital signal processor, a microphone and speaker, a variety of hardware keys and interfaces, and a liquid crystal display (LCD). The operating system (OS) of the device is held in ROM, which with the proper tools typically can be erased and reprogrammed electronically. For certain models, RAM may be used to store user data that is kept active by batteries; these data will be lost through failure or exhaustion of the batteries. The tests below were designed to detect cellular phones and focusing on the microphone, speaker, and RF system as potential vulnerability entry points.

\section{RF Transmission Technique}

Each cell phone was placed in the bottom of a simple metal enclosure with a whip antenna about 4" away. The RF spectrum within the metal enclosure was measured for the duration of the test. In figures $1-7$ below, the red signals standing alone are frequencies in which the cellular phone could be discriminated from the background signals: 


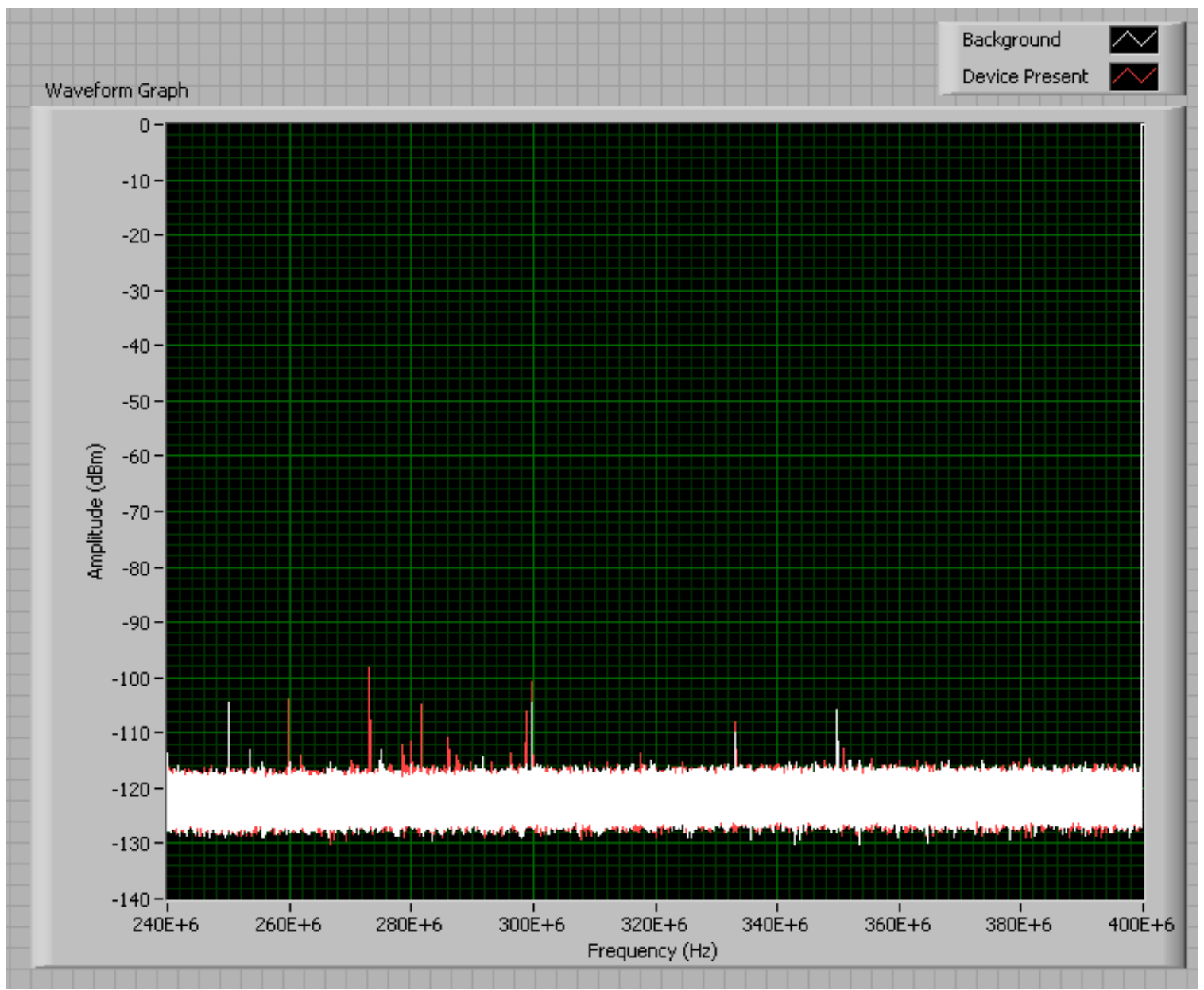

Figure 1 - New LG Cell Phone

The LG cellular phone had distinctive signals from $260 \mathrm{MHz}$ to $300 \mathrm{MHz}$. 


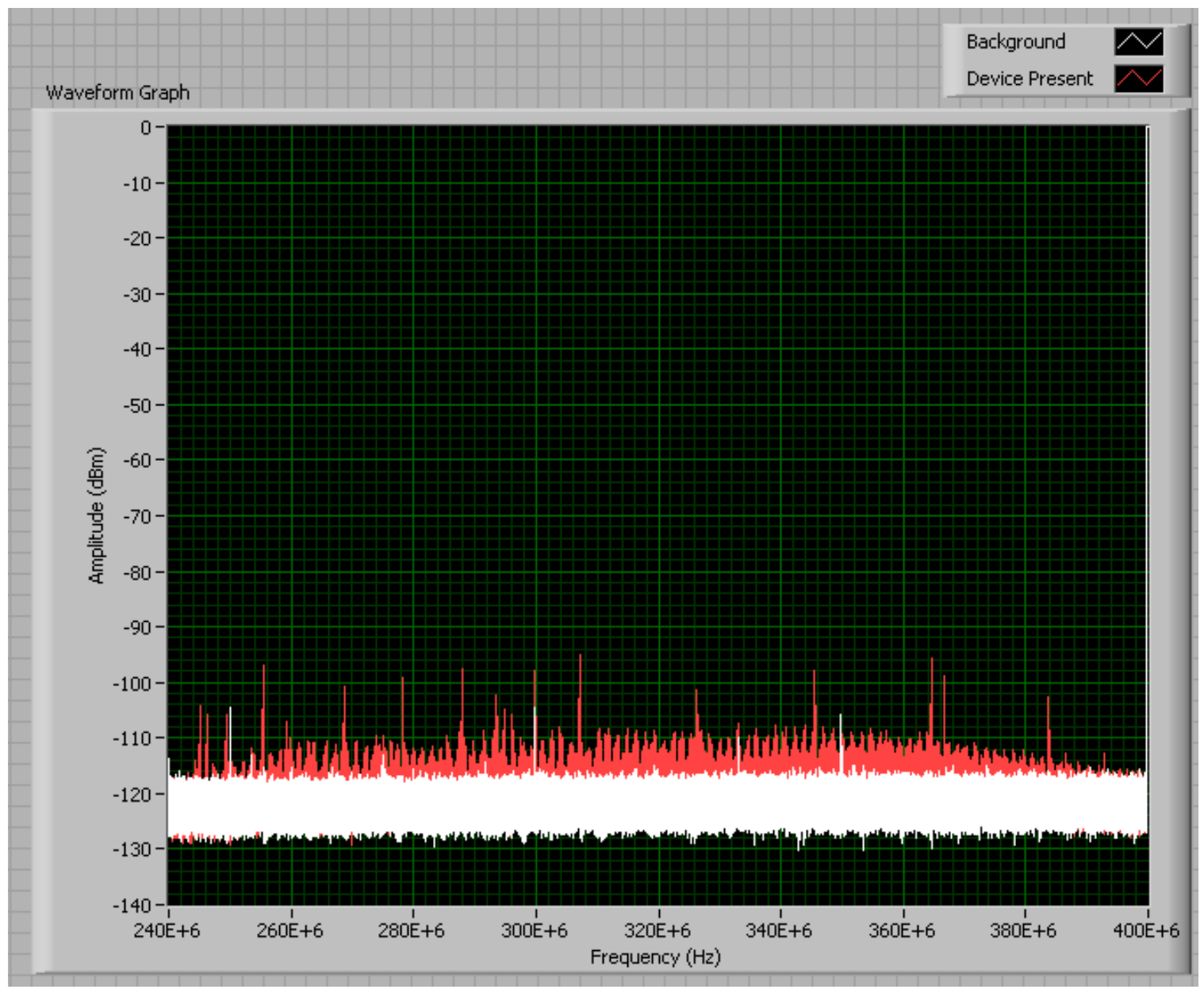

Figure 2 - New Motorola Cell Phone

The Motorola cell phone had distinctive signals over the entire band. 


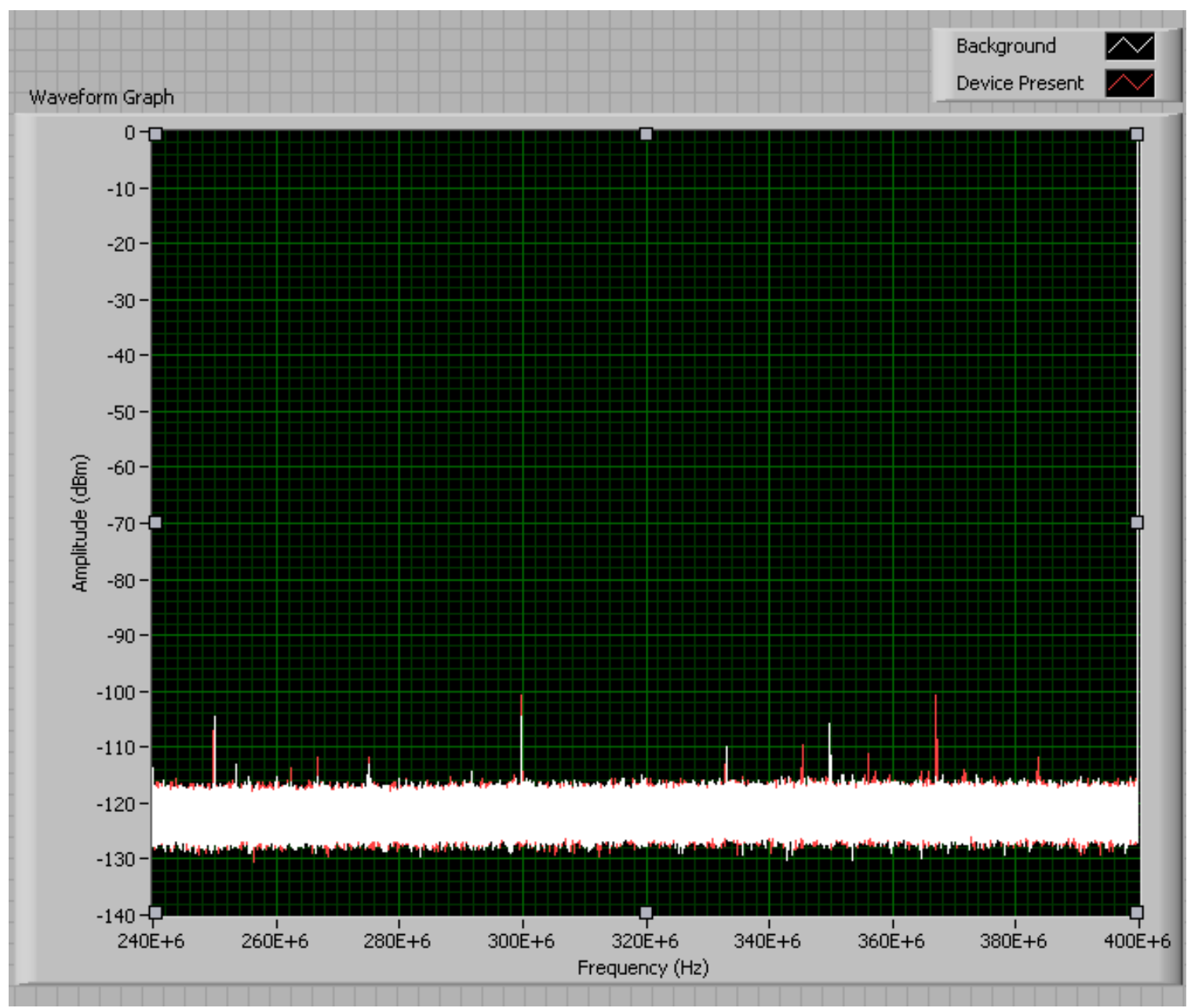

Figure 3 - Old Samsung Cell Phone

The Samsung cell phone had distinctive signals between $340 \mathrm{MHz}$ and $385 \mathrm{MHz}$. 


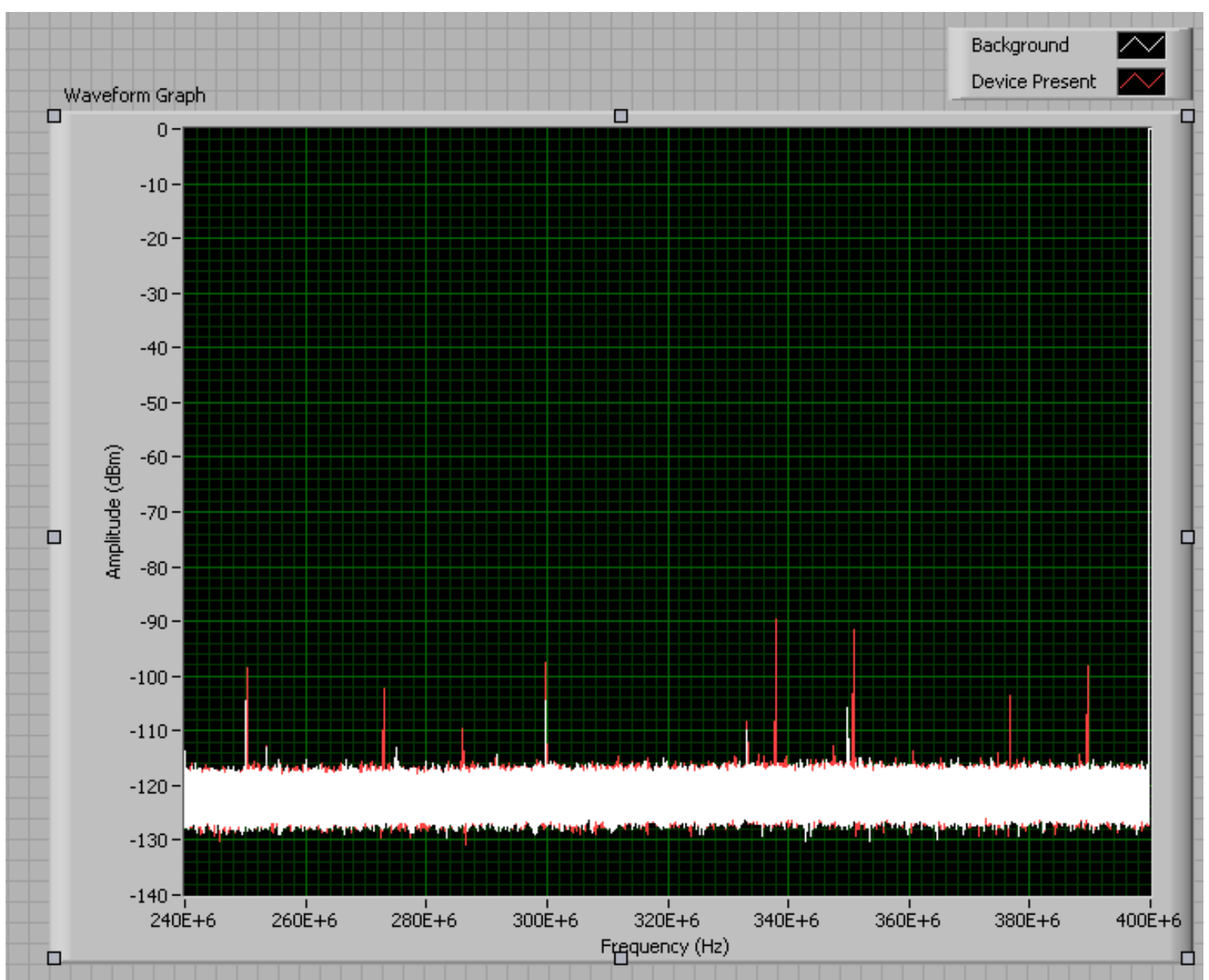

Figure 4 - Motorola 550

The Motorola 550 cell phone had several distinctive signals over the entire band. 


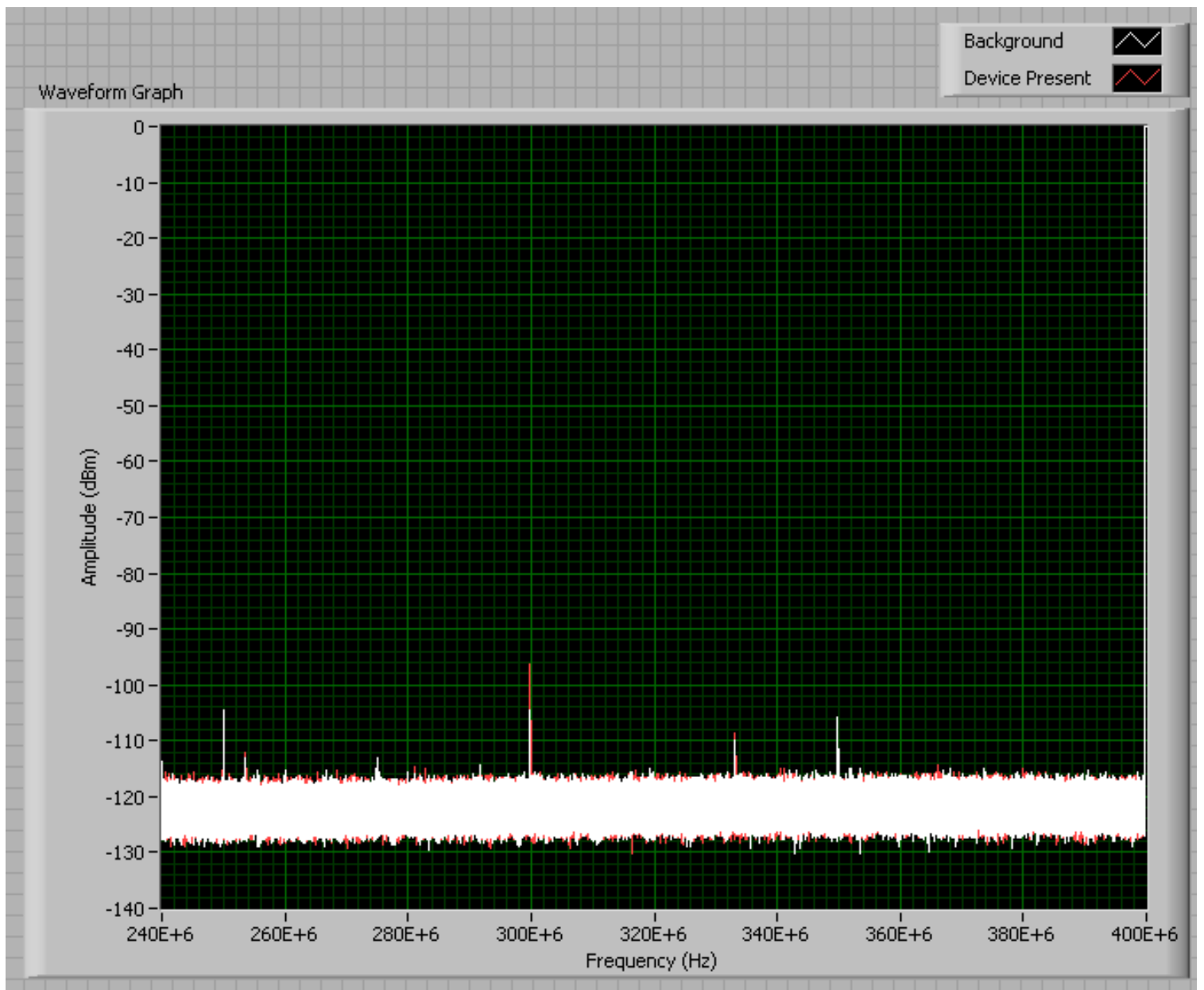

Figure 5 - Iphone

Detecting the Iphone will require additional testing. 


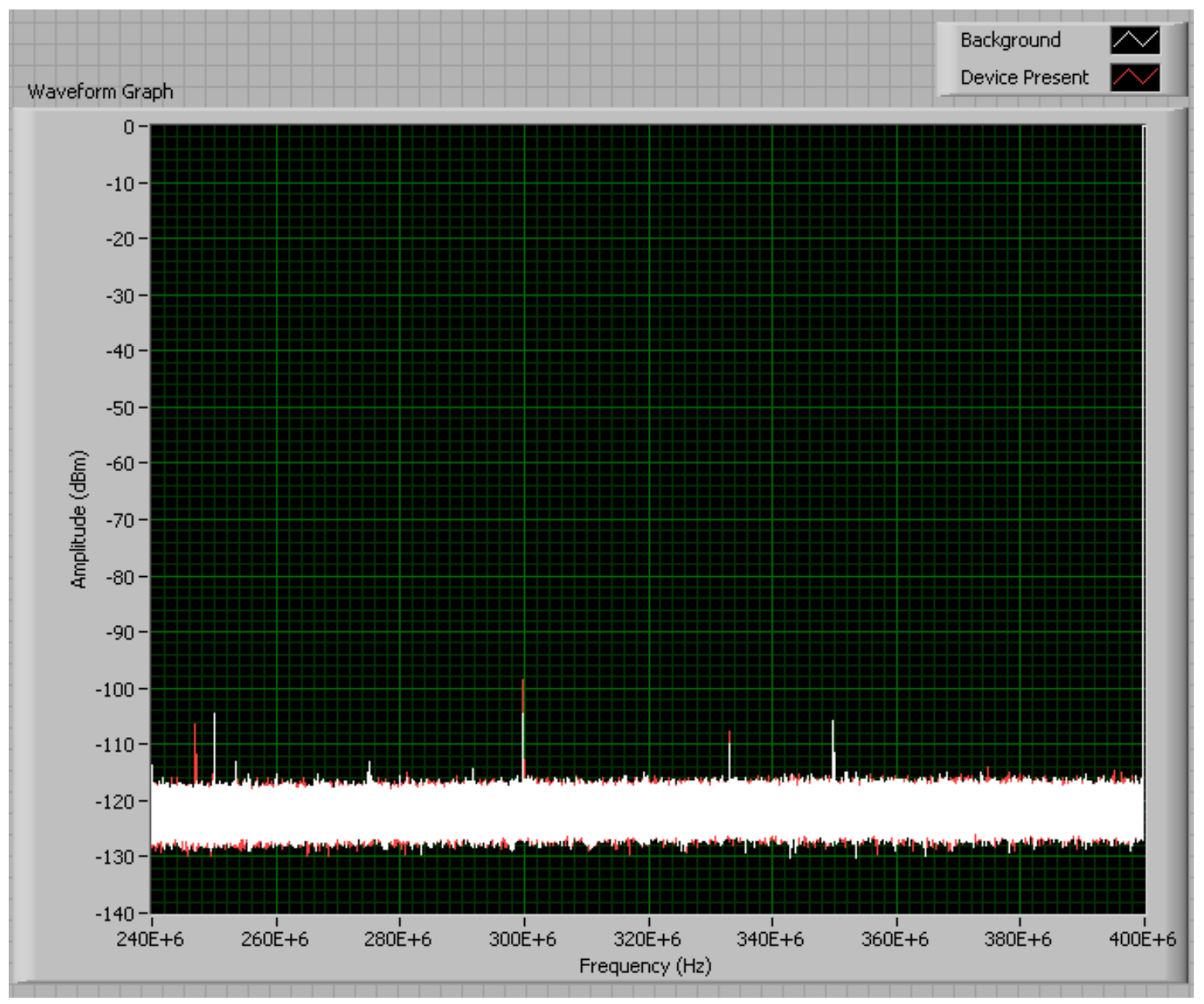

Figure 6 -Older Nokia

The older Nokia has one distinctive signal at $245 \mathrm{MHz}$. 


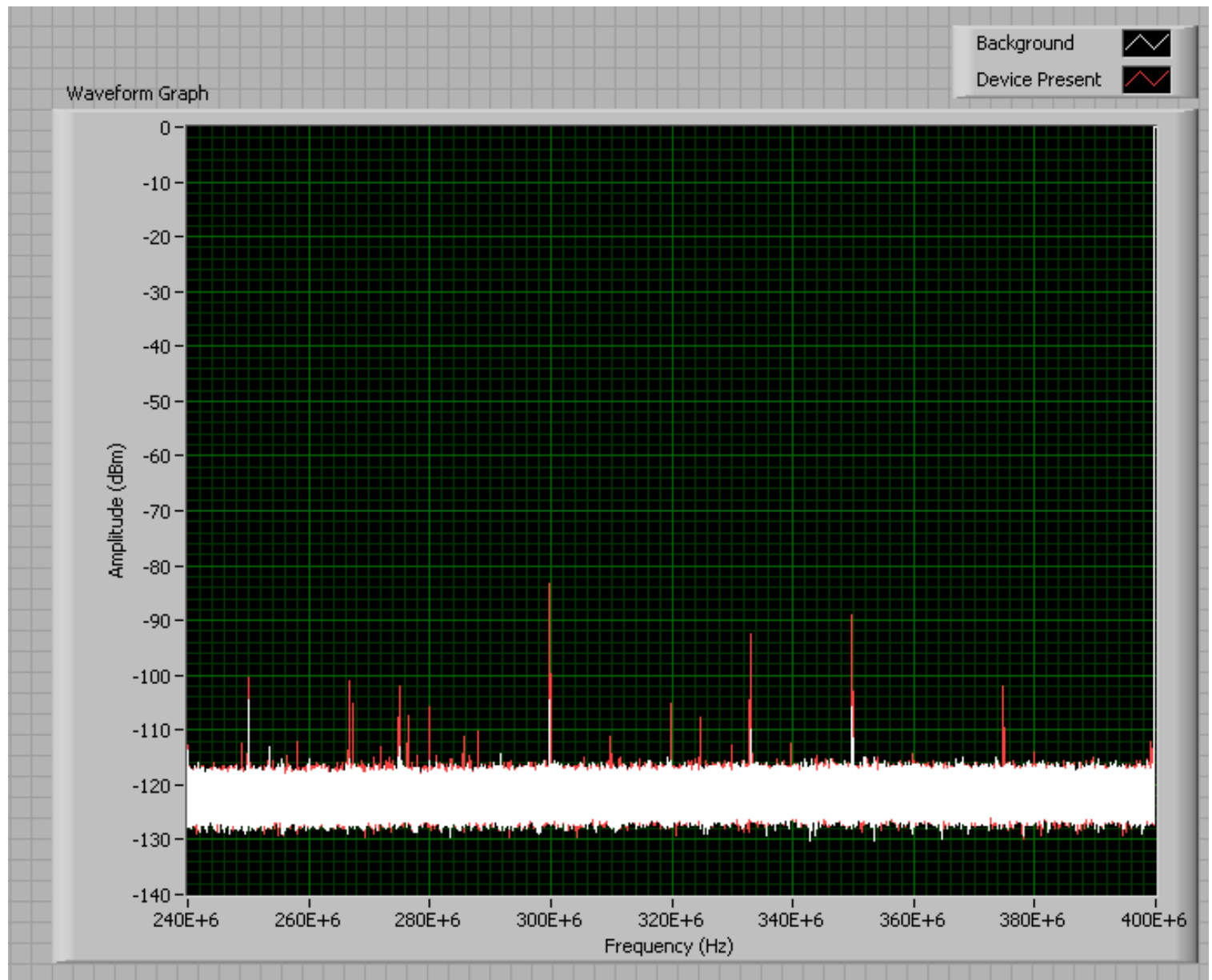

Figure 7 - No Device Lid Open

This scan defines the technical approach that will be required to successfully determine if a cell phone is in the immediate area. The red lines show signals that will need to be masked by the system so that the introduction of a cell phone can be detected. It is proposed that a passive infrared detector be included in the system to detect the presence of a person at the entrance to a limited area. Its function will be to cause the Cell Phone Detector to transition from measurement of the background signals into the cell phone detector mode. 


\section{Cell Phone Testing Conducted}

Ten methods of detecting cellular phones were conducted - each attempting to exploit a set of cellular telephone features. Cellular telephones actually have two speakers - one for the ringer and one for listening. The ringer speaker has a much larger magnet. A variety of tests were conducted to determine if these magnets could be reliably detected using eddy current instrumentation and "Hall Effect" sensors. Neither of these tests achieved the desired results.

The second effort scanned the RF frequency spectrum around the cellular phone. This test was looking for the internal oscillators necessary to operate the microprocessor and RF synthesizer / mixer. It was obvious from the absence of signal in the RF spectrum that the cellular phone designers had done a very good job meeting the electromagnetic interference specifications.

A third effort involved the use of mm-wave holography and techniques similar to that used by non-linear junction detectors. A sample test setup and image is shown below with red arrows connecting scanned objects to the objects themselves. The cellular phones were OFF in these images.

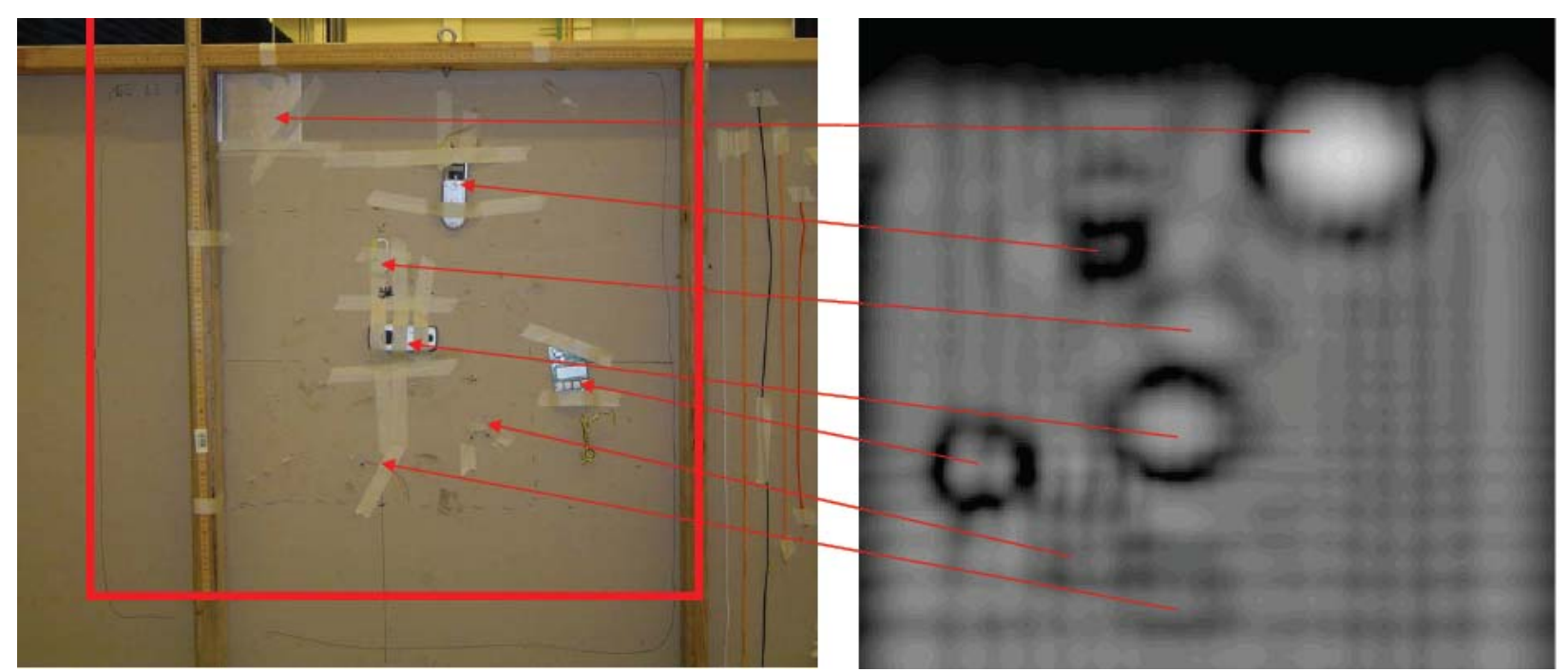

Figure 8 - mm-wave imaging technique

A fourth set of tests involved detecting the transmitted RF from the cellular phone. An "RF Signal Strength" meter was obtained along with an amplifier, mixer, and filter. This technique had no difficulty in detecting the cellular phones as they periodically communicate with the cellular tower. We began to investigate whether or not we could externally initiate the cellular phone to broadcast to the base station, but placed this effort on hold until after the Design Review.

A fifth option was selected. A commercial product was identified from a company called CellBusters. They manufacture a device that continuously monitors for cellular phones, once it detects that a cell phone is switched on (up to 90 feet away) it will alert the phone user that they must switch off their phone. All units are on back order and cost $\$ 755$ each. The CellBuster, when turned on, will continuously monitor for radio waves emitted from wireless communication devices. The device doesn't transmit and only receives signals, therefore is safe 
to use in areas sensitive to Cell phones and two-way radios. The unit can even detect Cell phones hidden in handbags and briefcases. Unfortunately of the 5 reviews written, two units did not work.

The sixth option involved combining RF and acoustic signals to detect the cellular phones. Three sets of tests were performed on 5/23/2007 to determine the technical feasibility of various approaches to identify if a person was carrying a cell phone into a limited area as a result on their oversight. The Magnetic Coupling Test coupled magnetic energy into the cell phone and observing a response. Second Harmonic Test used a modified second harmonic technique where the fundamental frequency was modulated at $3 \mathrm{kHz}$. Combined Audio and RF Test used an audio source and observed the detected RF response. 
Magnetic Coupling Test Setup.

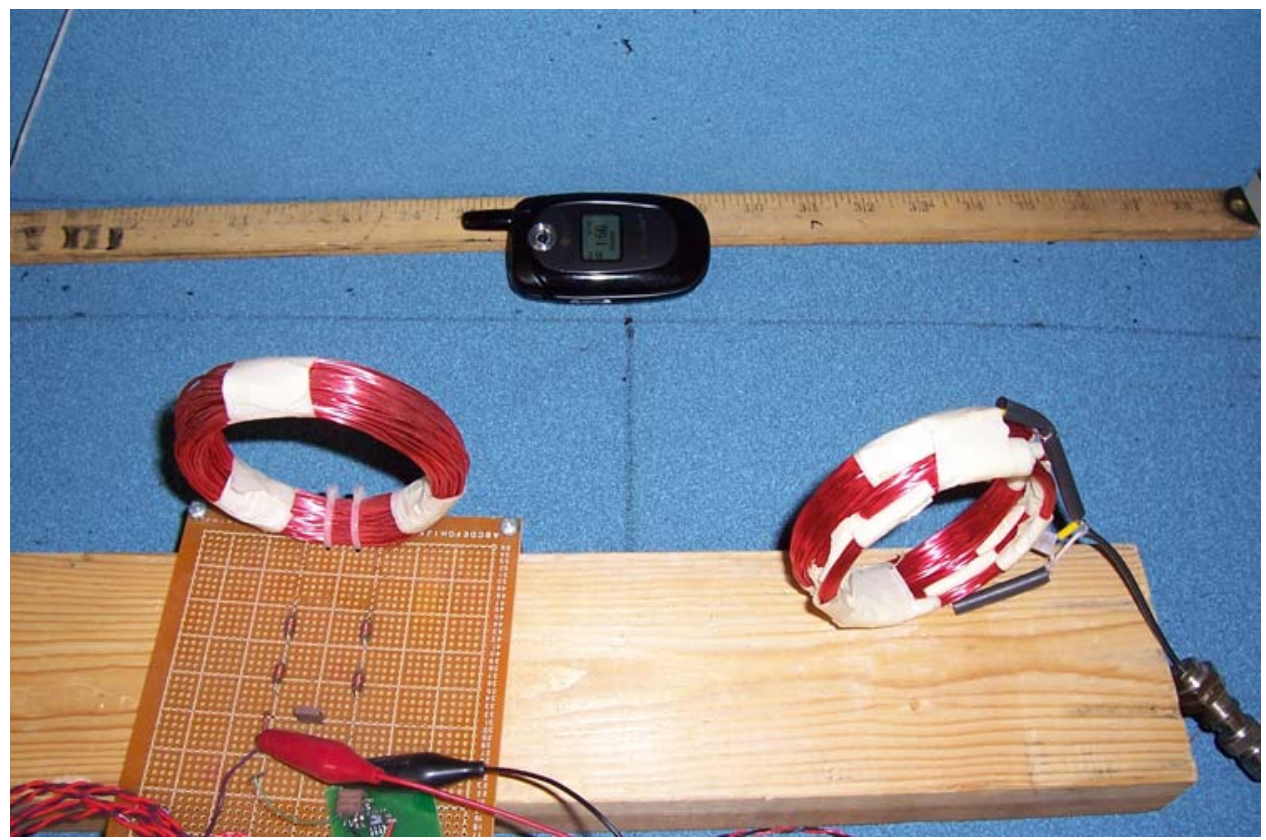

Figure 9 - Magnetic Coupling Test Setup - 28MHz Coils

This test configuration was a frequency synthesizer driving one coil at $28 \mathrm{MHz}$ and the spectrum analyzer monitoring the output of the second coil. The cell phone's presence or position relative to either coil made no change in the observed signal from the second coil.

\section{Second Harmonic Test Setup}

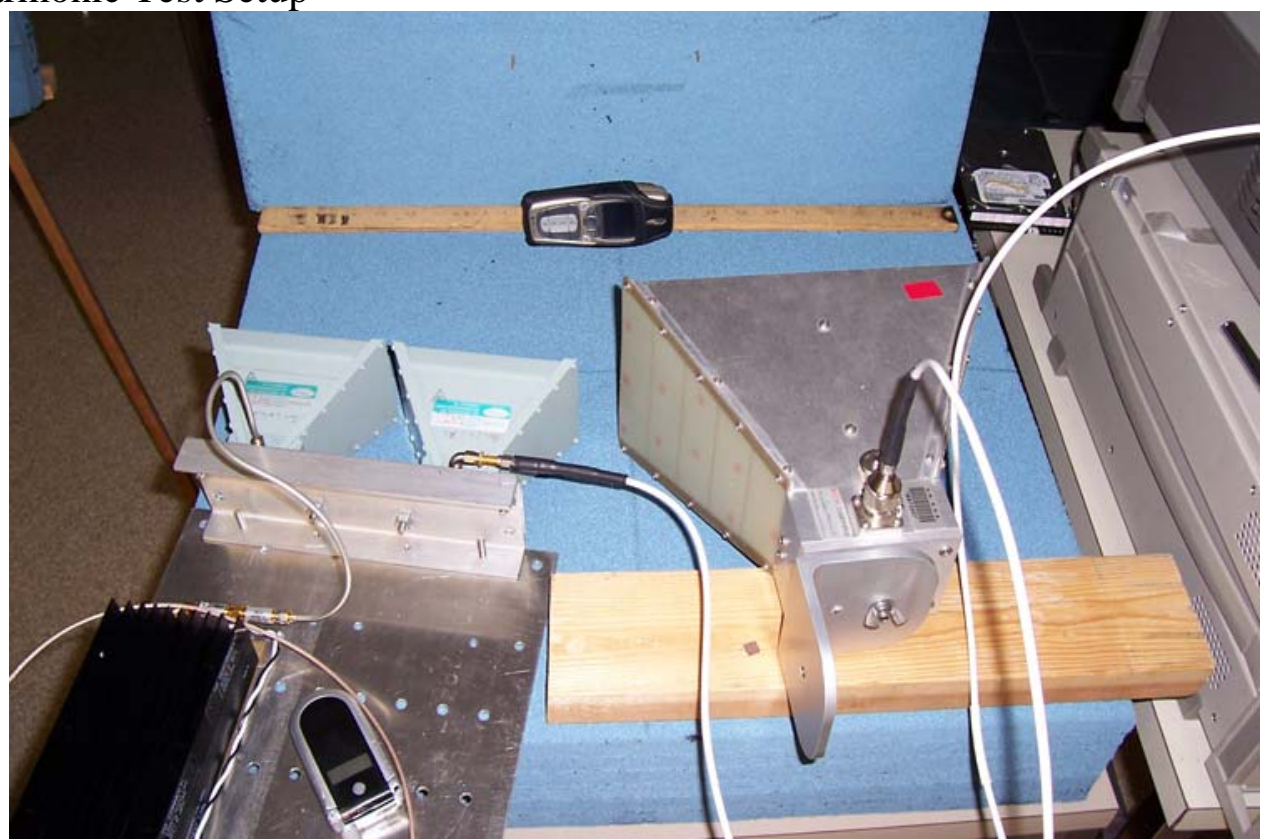

Figure 10 - Second Harmonic Test Setup - Modified Non-Linear Junction Detector 
Second Harmonic Test was a modified version of how a non-linear junction detector operates. The horn antenna on the right was connected to two low-pass filters, then a $40 \mathrm{dBm}$ power amplifier, and then to a frequency synthesizer. The small horn antenna on the left was directly connected to an RF spectrum analyzer. The RF spectrum analyzer was configured to demodulate AM signals (similar to an AM radio).

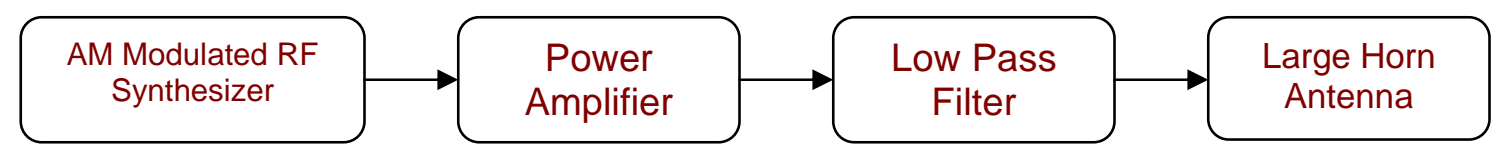

Combined Audio and RF Test Setup

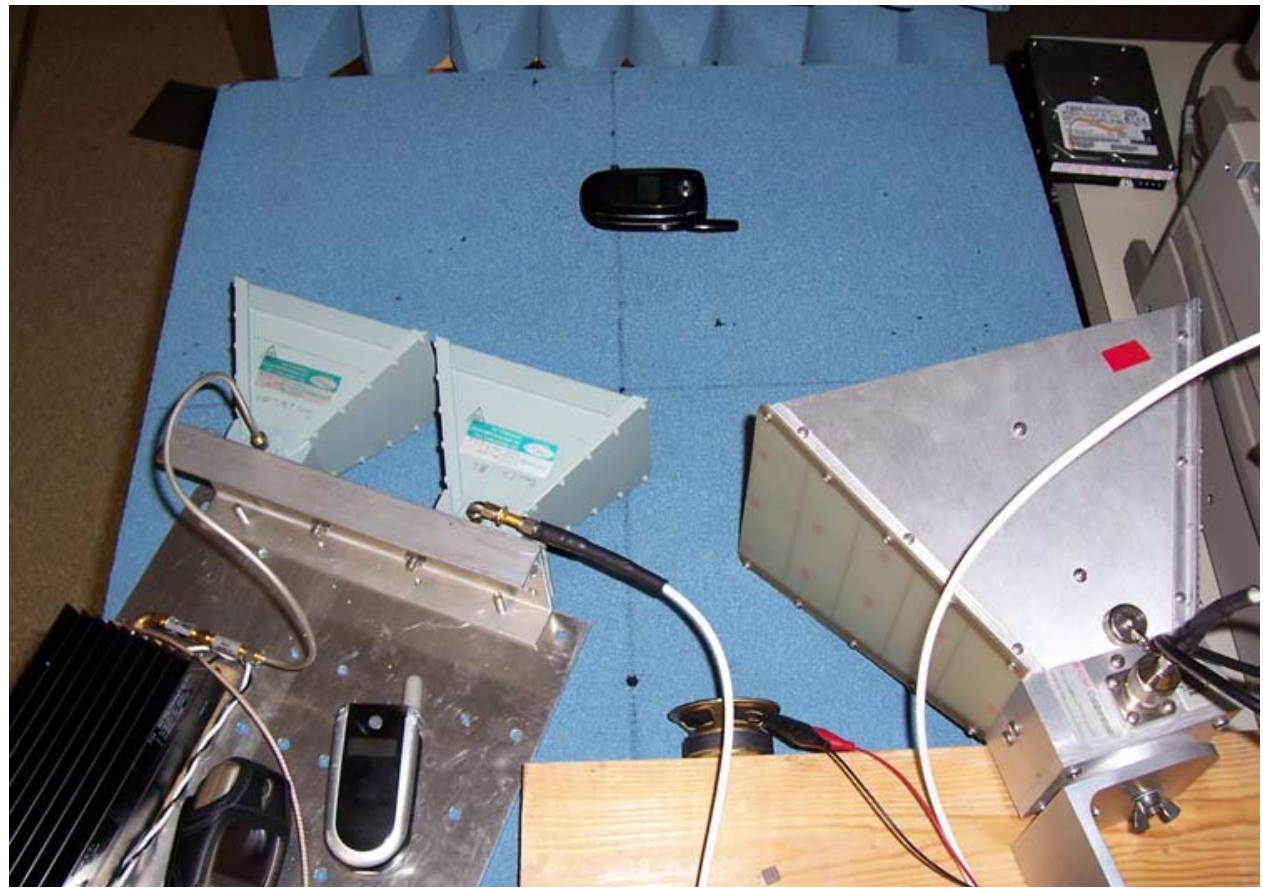

Figure 11 - Combined Audio and RF Test Setup - Acoustic Modulated RF Signal

Combined Audio and RF Test replaced the AM Modulated RF Synthesizer used in Test \#2 with an RF Synthesizer and removed the low pass filters. (A continuous wave RF signal was used). The horn antenna on the right was connected to a $40 \mathrm{dBm}$ power amplifier, and then to a frequency synthesizer. The small horn antenna on the left was directly connected to an RF spectrum analyzer. The RF spectrum analyzer was configured to demodulate AM signals. This test added an audio speaker (located between the antennas) to try to make the cell phone's microphone (or speakers) react to the audio signal. The RF transmitter and receiver would then be used to sense the cell phone reacting to the audio signal.

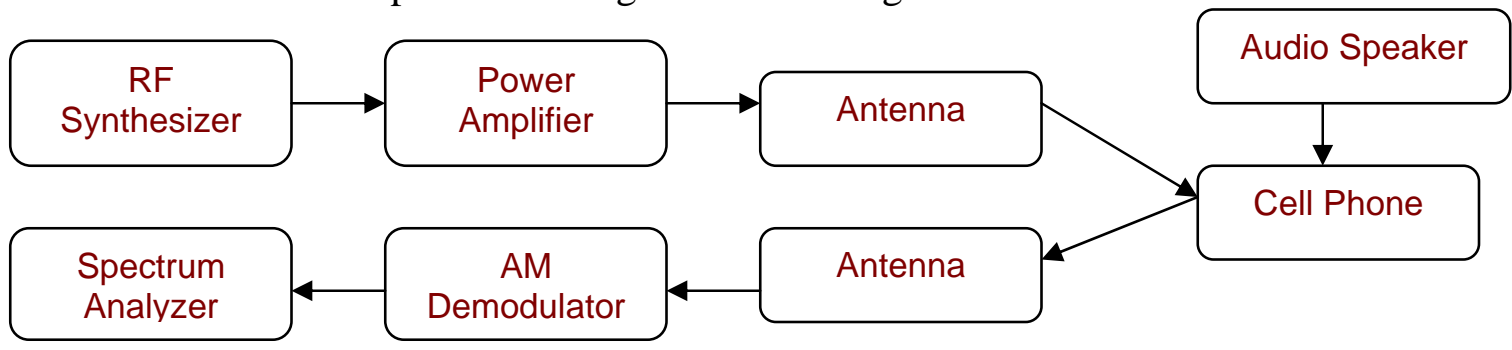


Magnetic Coupling Test Results

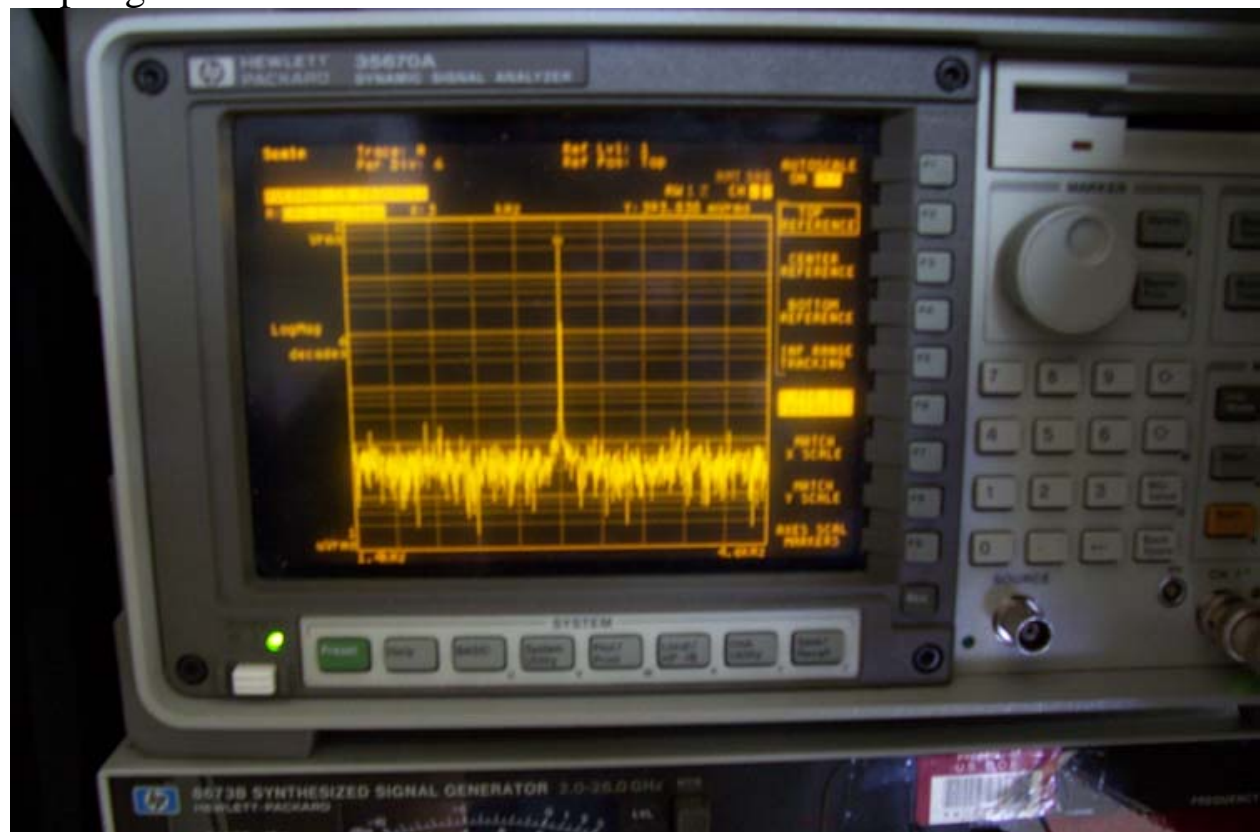

Figure 12 - Typical Magnetic Coupling and Second Harmonic Test Results

The spectrum analyzer shows a typical response from the $28 \mathrm{MHz}$ coils when the driven coil was modulated with $3 \mathrm{kHz}$. Unfortunately, the signal amplitude did not change as a result of the cell phone being in the field.

Second Harmonic Test Results:

The typical response from this was identical to response shown in Test \#1. A key observation was that the body presence could also make significant changes in the signal amplitude. Additional body distance from the antennas helped, but the presence of the cell phone did not create enough additional signal to mitigate body presence issues.

Combined Audio and RF Test results are encouraging when they occur. Power to the antenna was $+30 \mathrm{dBm}$ (FCC specification) at $2.7 \mathrm{GHz}$ and the speaker was driven with $1 \mathrm{~V}_{\mathrm{pp}}$ at $2.5 \mathrm{kHz}$ and $55 \mathrm{~dB}_{\mathrm{SPL}}-$ normal speech is $70 \mathrm{~dB}$ ). This is not too loud to have in an access area. When no phone was present there was no signal present (see figure below). This signal is the AM demodulated fundamental frequency. I tried going higher in frequency, but that did not seem to help. The phone definitely does not respond when shielded with my hand. 


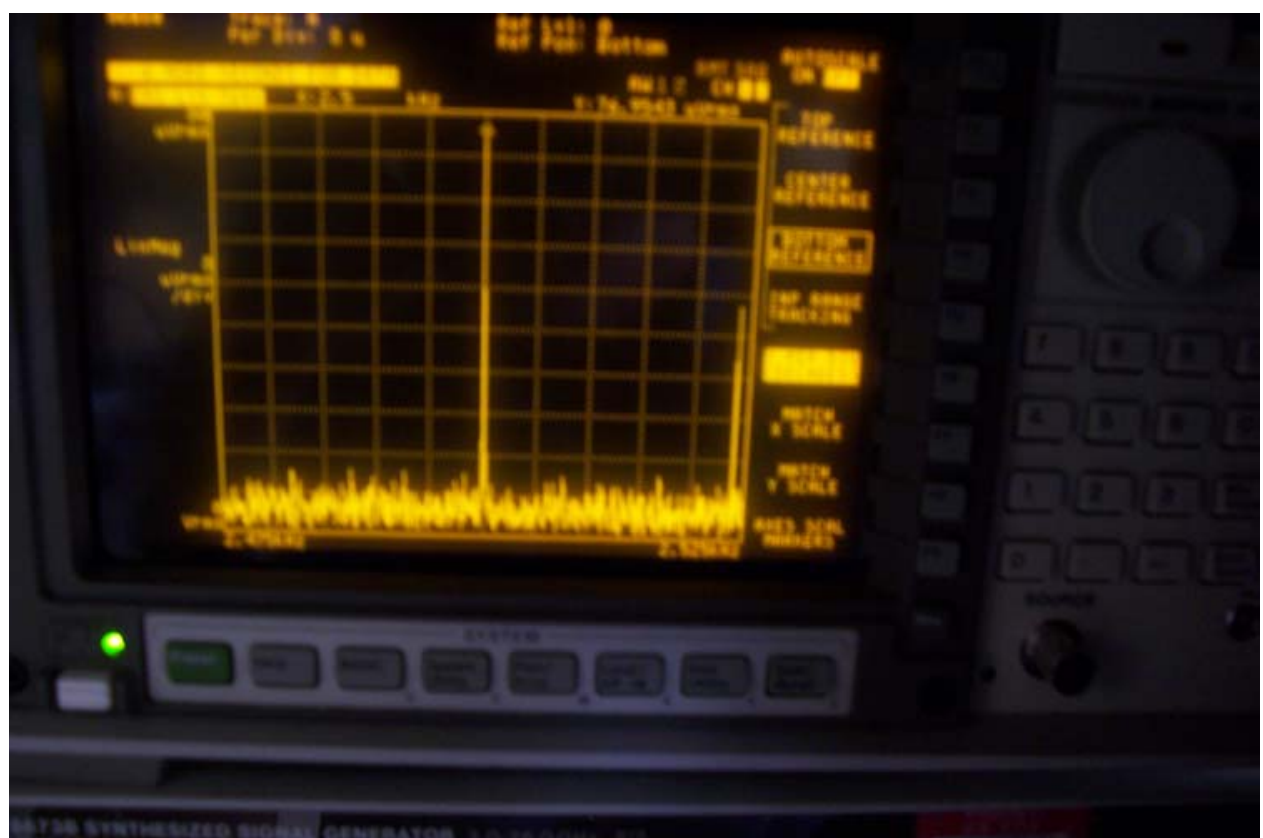

Figure 13 - Combined Audio and RF Test Results

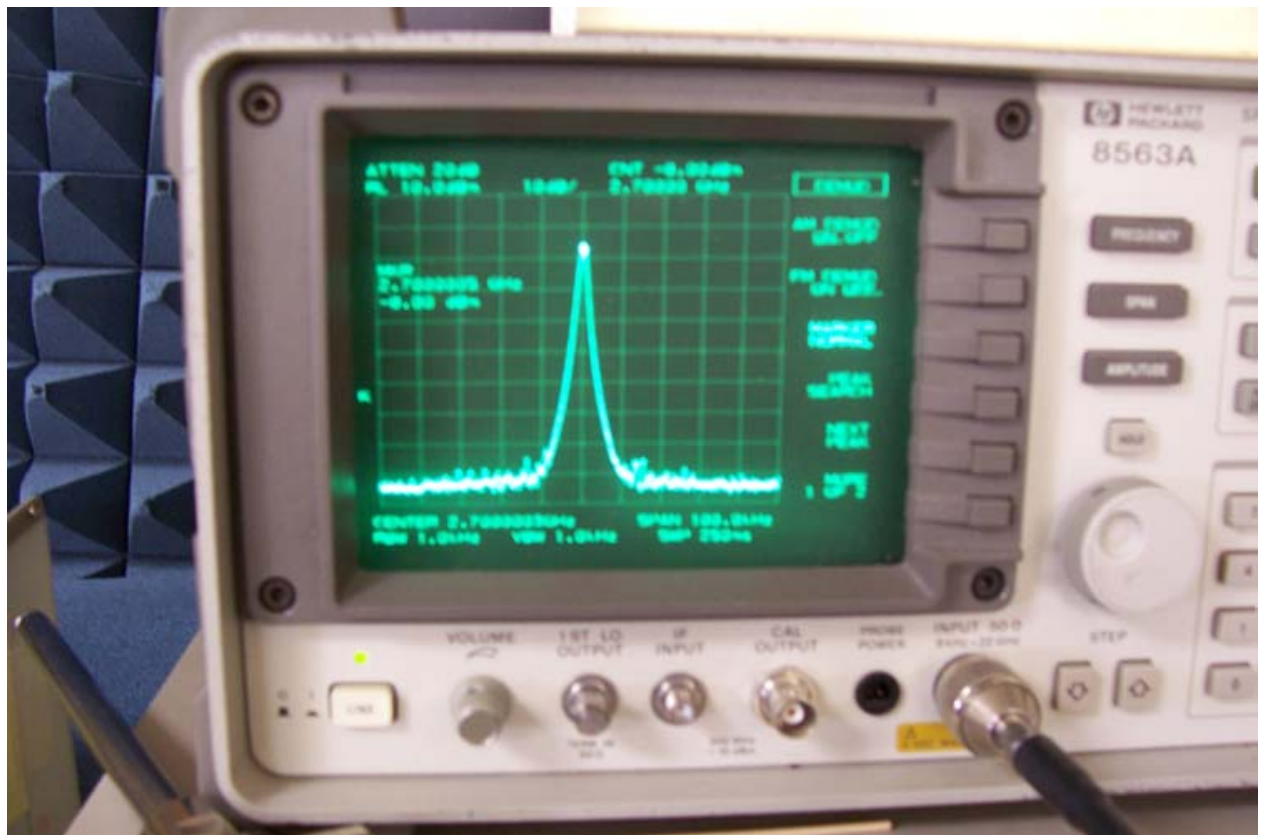

Figure 14 - Combined Audio and RF Test RF Spectrum Analyzer Signal

Seventh - Capacitive Sensor technique. A sensor similar to the one shown below was used to detect the cellular telephone. This sensor capacitively couples lower frequency energy from the phone into the sensor. This actually worked pretty well when the cellular phone was ON and within a few inches of the sensor. No external stimulus was used. 


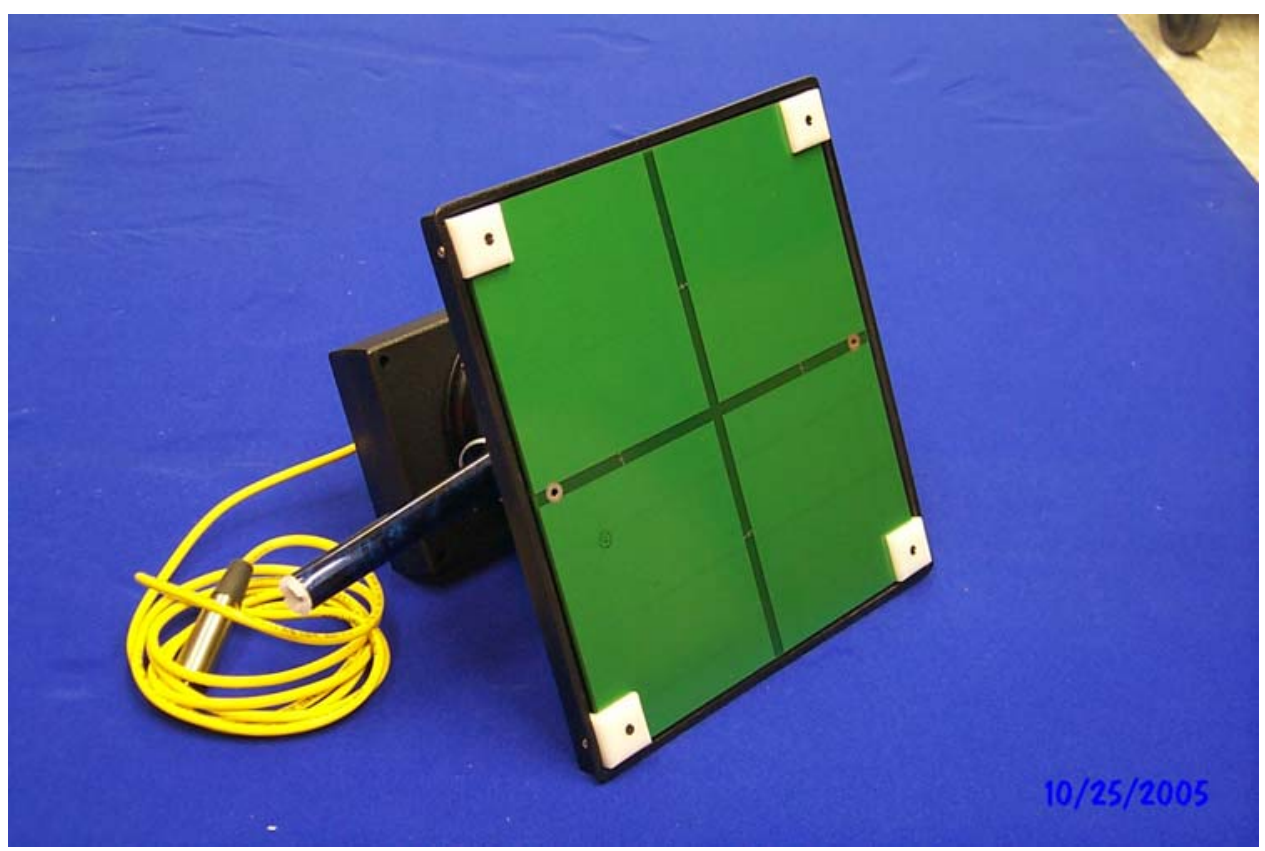

Figure 4. Capacitive Sensor

Eighth - active tags - since this is a commercial technology and has been demonstrated at Savannah River and Oak Ridge, no work has been done in this area so far. PNNL does own a Rubee evaluation kit. RuBee (IEEE P1902.1) is a two way radio tag protocol that uses Long Wave (LW) magnetic signals to send and receive data packets in a local regional network. The standard is in its final stages of approval by the IEEE. However the protocol has been in commercial use in asset visibility systems and networks for several years. RuBee radio tags are networked radiating transceivers, but operate at $131 \mathrm{kHz}$. IEEE P1902.1 is the physical layer workgroup and was formed in late 2006 with the final specification expected early 2008.

A typical RuBee Radio Tag - Has a 4 bit CPU, 1 Kbyte SRAM, crystal, and Li battery with expected life of five years. A typical RuBee radio tag about 1" x 1" by .070", has a 4 bit CPU, 1-5 Kbytes SRAM, a clock, optional sensors, and can have displays and buttons.

RuBee is a battery-powered, bidirectional, on-demand, peer-to-peer protocol and can operate at other frequencies. This protocol functions successfully in harsh environments

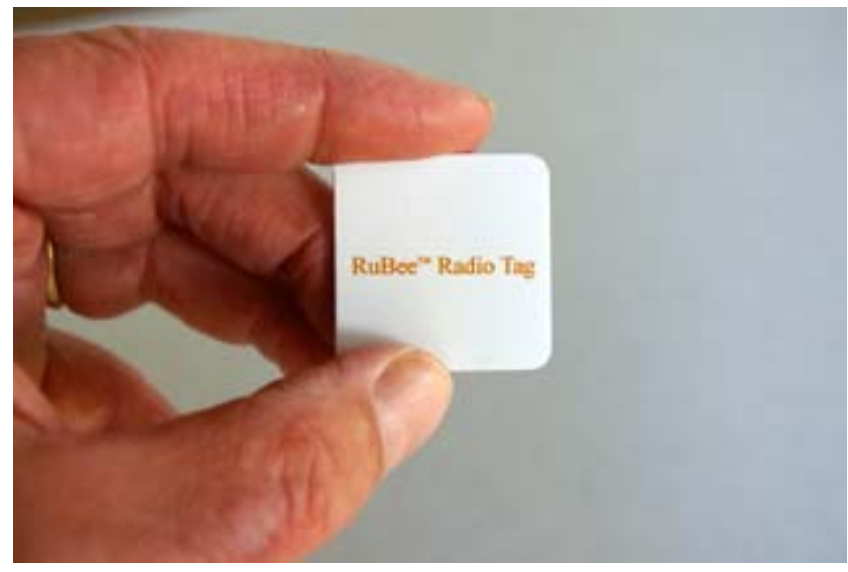
with networks of many thousands of tags and has a range of 3 to 100 feet depending on the antenna configuration. By 'harsh environments' is meant the ability to read and write data near steel or water. RuBee radio tags function in environments where other radio tags and RFID may have problems. 
Summary Single Method Estimated Detection Chart

\begin{tabular}{|l|c|c|c|c|c|c|}
\hline \multicolumn{1}{|c|}{ Method } & $\begin{array}{c}\text { Range } \\
\text { ON }\end{array}$ & $\begin{array}{c}\text { Range } \\
\text { OFF }\end{array}$ & $\begin{array}{c}\text { Range } \\
\text { Transmitting }\end{array}$ & $\begin{array}{c}\text { Cost } \\
\text { Portal }\end{array}$ & $\begin{array}{c}\text { Cost } \\
\text { Tag }\end{array}$ & $\begin{array}{c}\text { Reliable } \\
\text { Reads }\end{array}$ \\
\hline Magnetic & N/A & N/A & N/A & & $\$ 0$ & \\
\hline RF Spectra & $\begin{array}{c}\text { Test not } \\
\text { Complete }\end{array}$ & $\begin{array}{c}\text { Test not } \\
\text { Complete }\end{array}$ & $\begin{array}{c}\text { Test not } \\
\text { Complete }\end{array}$ & & $\$ 0$ & \\
\hline mm-Wave & $50 \mathrm{~cm}^{(1)}$ & $50 \mathrm{~cm}^{(1)}$ & $50 \mathrm{~cm}^{(1)}$ & & $\$ 0$ & \\
\hline Phone RF & 10 meters & N/A & 10 meters $^{(2)}$ & & $\$ 0$ & \\
\hline Commercial & N/A & N/A & 10 meters $^{(3)}$ & & $\$ 0$ & \\
\hline RF/ Audio & $1 \mathrm{~cm}^{(5)}$ & $1 \mathrm{~cm}^{(5)}$ & $1 \mathrm{~cm}^{(5)}$ & & $\$ 0$ & \\
\hline Darwin & $5 \mathrm{~cm}$ & N/A & $5 \mathrm{~cm}^{(3)}$ & & $\$ 0$ & \\
\hline Rubee Tags & $1 \mathrm{~meter}(3)$ & $1 \mathrm{~meter}(3)$ & $1 \mathrm{~meter}^{(3)}$ & & $\$ 10$ & \\
\hline Passive Tags & $1-2 \mathrm{~cm}$ & $1-2 \mathrm{~cm}$ & $1-2 \mathrm{~cm}$ & & $\$ 1$ & \\
\hline Enhanced NLJD & $50 \mathrm{~cm}$ & $50 \mathrm{~cm}$ & $50 \mathrm{~cm}^{(3)}$ & & $\$ 1$ & \\
\hline
\end{tabular}

(1) All testing done at 50 centimeters. This technique is in its early R\&D stages.

(2) Based on measured 0dBm transmitted signal level.

(3) Based on specification sheet.

(4) Technically possible to implement a "Base Station" and cause communications to initiate

${ }^{(5)}$ Difficult to get consistent test results using this method

Multiple Detection Method Approaches

Method 1 - Combined Passive RFID Tag and Cell Phone - This method was tested during Rubee testing at Oak Ridge / Savannah River and found to be unreliable. Measured detection range was only a few centimeters.

Method 2 - Enhanced Non-linear Junction Detector (NLJD) Method. This method added a very simple RFID tag (only a diode and the tag's antenna) to the outside of the cell phone case and detection range was evaluated. Good detection was measured out to about $50 \mathrm{~cm}$ using test equipment with the phone ON or OFF. We will need to work through antenna / phone orientation issues.

Also considered were using magnetic or optical approach, but plausible implementations were not conceivable. 


\section{Appendix A \\ CellBusterSpecification}

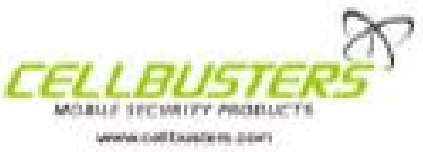

Cellbusters.Com 3240 E Hiddemiew Drive, Phoenlx, Arizona, 85048, USA.

Phone: 602-550-1172. Fax: 928-438-22,02

emali: derek.fordedicellbusters,com, web: Www.cellbusters.com

Cellbuster Cell Phone Detector:

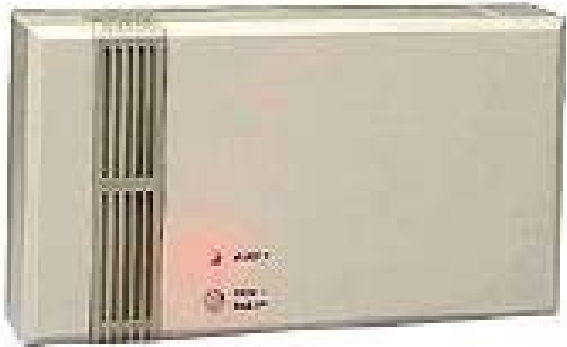

- Detect and prevent unauthorized cell phone usage.

- Automatically Alerts cell phone users to switch off their phone.

- Simple to setup, un and running in minutes.

- Range adjustment for spectic area

detection

- Muitiple alert options

- Made in the USA, 100 \% leqal

The Cellibuster is a device that continuously monitors for cellatar phones, once it detects that a cell phone is switched on (up to 90 feet away) it will alert the phone user that they must switch off their phone.

\section{CellBuster Features:}

- Audio alert "asks" cell phone users to switch off their phone.

- Red Alert light flashes brightiy to attract attention to the device if operating in audio slient mode.

- Even detects when a phone is switched on and not in use (eg. handbag or pocket)

- Easy to configure with choice of alert modes, volume and sensitively control.

- Simple to Install no skills required - up and nunning in minutes.

- $100 \%$ Legal in USA, Europe and all other countries.

- Funs on four batteries which last over a year

- Saves you the embarrassment of asking someone to switch off their Cell phone.

- Remernber people ignore "Cell phones are not permitted" signs

How does the CellBuster work?

The Celibuster, when turned on, will continuoushy monitor for radio waves emitted from wireless communication devices. The device doesr't transmit and anty receives signais, therefore is safe to use in areas sensitive to Cell phones and two-way radios. The unit can even detect Cell phones hidden in hand hags and briefcases.

When a signal is detected, for instance a person carrying a Cell phone in standby mode, a user seiectable aburm is sounded. The unit has three alarm types.

Voice/Tone mode allows the unit to give a series of tones to alert the presence of a Cell phone, or a tone alert followed by a voice message requesting the user to stop using their communications devion.

Alarm light mode flashes a bright red light, ideal for slent detection or for drawing attention to the volce message.

Remote ahrm mode allows the device to send a remote signal to another device such as a security system, data logging or survellance application. 


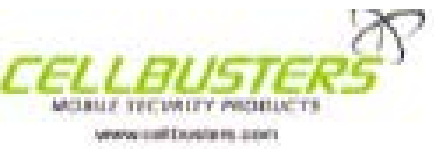

Cellbusters,Com 3240 E Hiddenview Drtve, Phoenix, Arizona, 85048, LSA.

Phone: $602-550-1172$. Fax: $928-438-2202$

emal: derek,fordedicellbusters.com, web: www,celibusters,com

One, two, or all three alarm types can be used in conjunction with each other, ideally suiting your needs for monitoring Cell phone or two-way radio use.

Where can the Cellisuster be used?

The CellBuster is ideally suited to mamy purposes and situations. It can be used to enforce Cell phone restricted areas such as Hospitals, Power Plants, Airports, Medical Clinics, Compute: Fooms, Transportation Operations, Industrial Plants, Control Roorns, and Laboratories.

It can be used for Privacy and Security purposes where sensitive information needs to be protected, such as in lusiness Meetings, Financlal Institutions, Courthouses, Government Buildings, Legal Briefings, Embassies, Political Meetings and Defence Facilities.

Some Examples:

Untawful Activities can be prevented at such locations as Baniks, Prisons, Security Services Firms, Detention facilties, Police Departments, Garning Facitities, and Facilty Management Operations. Ey installing a Cellbuster you can monitor and protect yourself and business from unlawful use of Cell phones.

Cell phone nolse pollution can be prevented in Restaurants, Bars, Privacy Rooms, Public Transport, Classtooms and Lecture Halls, Cinemas, Theatres, Golf clab houses, hospltality roorns, and Church Events.

\section{CellBuster Specifications:}

- $100 \%$ Legal in USA, Europe, and all other countries.

- Informs Cell phone users to switch off their Cell pbone.

- Fits anywhere, just 20Wx11.2HxSD(cm). $8 W \times 4.5 H \times 2 D$ (Inches).

- Buit in alarm speaker.

- Weight including internal batteries is approx $2.1 \mathrm{lbs}$ or $1 \mathrm{Kg}$.

- Easy to wall mount or can be used as a portable device

- Battery powered (4x'C cells) or 9v DC input jack for AC adapter (not included). Battery life is approx 1 year.

- Remote alarm output, for connection to security station or external alarm.

- Audio output for connection to external speaker.

- Integrated internal antenna, to avoid protrusions or tampering.

- Detects mobile phones and two-way rad los with frequencies from 400-2000Mitz

- Detects Analogue and Diqital Cell phones CDMA, TDMA, GSM and PCS/PCN types.

- Sensitivity control range of 2 to 30 meters. (Approx. 6 to 90 feet).

- Low battery audio indicator.

- Easily accessible controls behind front grille, for sensitwity control, spealker volume, Alarm light (Onjoff), Audio atarm typeivoice or tone), local audio alarm(Onyoff), and Mobile phone Standby Mode Detection(On/Off). 
Appendix B

Figure 16 (http://direct.xilinx.com/bvdocs/whitepapers/wp198.pdf) below shows a block diagram of a digital-type handset.

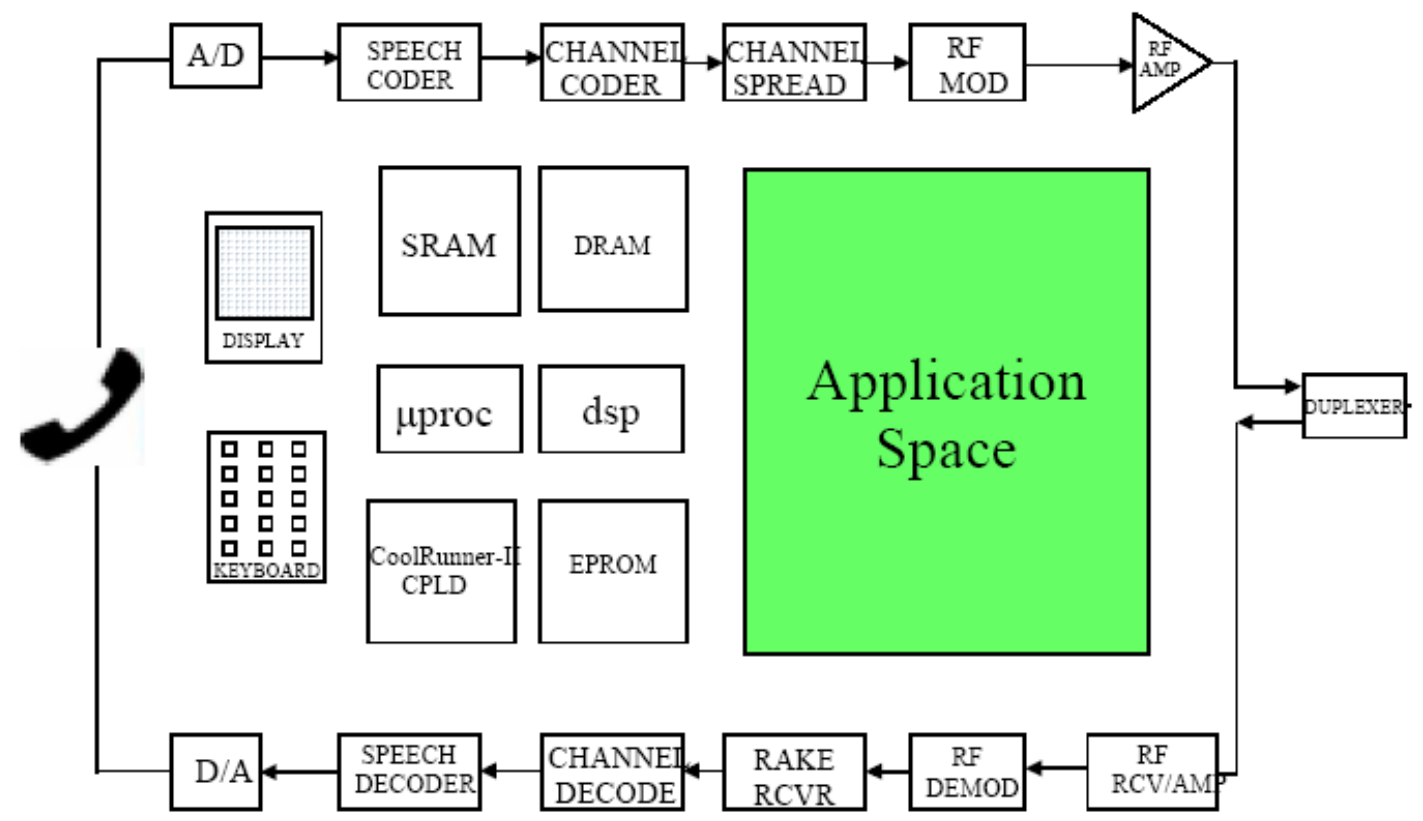

Figure 5. Functional Components of a Digital Handset / Terminal

Let's simply look at sending and receiving audio. The microphone delivers audio signal to the A/D converter, creating a bit-stream. Fidelity and efficiency require redundancy elimination and compression. This is done in the speech coder (typically adaptive multirate). Forward Error Correction (FEC) occurs in the channel coder (Viterbi today, Turbo tomorrow). Coding adds back redundancy, but dropped bits can be recovered. CDMA channel spreading has been introduced in the U.S. and Korea, but others may use TDMA, SCDMA or WCDMA. The digital signal finally gets to the RF modulator and RF amplifier where it becomes one of several signal types (again, depending on the phone standard). At this point, it is analog. Today, these are in the gigahertz range and focused on octal phase shift keying. The duplexer is inserted to switch between receiving and sending at the antenna.

On the receiving end, the signal hits the antenna, slides through the duplexer and is amplified and demodulated, becoming digital. The Rake Receiver "despreads" the received bits and forwards the signal to the channel decoder, which reconstructs the possibly corrupted digital signal and passes it on to the speech decoder. The speech decoder corrects bit-dropout and should resemble the digital version of the original analog signal. This forwards to the D/A converter, which, when filtered and amplified (not shown), drives the earphone.

But Figure 16 lacks the key items for our application - an access point into the cell phone to wake it up for reception of an incoming call. In the cases where the phone is ON, the GSM and UMTS systems use a Tree and Tabular Combined Notation to verify the protocol. 


\section{Appendix C Cellular Telephone Specifications}

- ANSI/TIA/EIA-41-D, Cellular Radiotelecommunications Intersystem Operations, December, 1997.

- ANSI/TIA/EIA-93-B, Cellular Radio Telecommunications Ai - Di InterfaceStandard, December, 1997. - TIA/EIA/IS-95-A, Mobile Station - Base Station Compatibility Standard for Dual-Mode Wideband Spread Spectrum Cellular Systems; Telecommunications Industry Association; May 1995.

- TSB74, Support for 14.4 kbps Data Rates and PCS Interaction for Wideband Spread Spectrum Cellular Systems, December, 1995.

- ANSI J-STD-008, Personal Station - Base Station Compatibility Requirements for 1.8 to 2.0 Ghz Code Division Multiple Access (CDMA) Personal Communications Systems.

- TIA/EIA-124-B, Wireless Radio Telecommunications Intersystem Non-Signaling Data Communications DMH (Data Message Handler); Telecommunications Industry Association; July 1999.

- TIA/EIA IS-136.1-A, TDMA Cellular/PCS - Radio Interface - Mobile Station -Base Station Compatibility - Digital Control Channel, Rev. A, October 1996.

- TIA/EIA IS-136.2-A, TDMA Cellular/PCS - Radio Interface - Mobile Station -Base Station Compatibility - Traffic Channels and FSK Control Channel, Rev. A, October 1996.

- EIA/TIA/IS-553, Mobile Station - Land Station Compatibility Specification; September 1989.

- TIA/EIA/IS-634, MSC - BS Interface for Public Mobile 800 MHz, December 1995.

- TIA/EIA/IS-634-A, MSC - BS Interface for Public Wireless Communications Systems, (to be published tbd).

- TSB80, MSC - BS Interface for Public 800 MHz, October 1996.

- TIA/EIA/IS-658, Data Services Interworking Function Interface for Wideband Spread Spectrum Systems, 1996.

- TIA/EIA/IS-737, IS-41-C Enhancements to Support Circuit Mode Services, (approved for publication).

- TIA/EIA/IS-683-A, Over-The-Air Service Provisioning of Mobile Stations In Spread Spectrum Systems, February 1997.

- TIA/EIA/IS-725-A, Cellular Radiotelecommunications Intersystem Operations - Over-The-Air Service Provisioning (OTASP) \& Parameter Administration (OTAPA), July 1999.

- TIA/EIA/IS-756-A, TIA/EIA-41-D Enhancements for Wireless Number Portability Phase II, December 1998.

- TIA/EIA/IS-771, Wireless Intelligent Network, July 1999.

- TIA/EIA/IS-820, Removable User Identity Module (R-UIM) for TIA/EIA Spread Spectrum Standards, March 2000.

- TIA/EIA/IS-839, R-UIM Overview, Operation and File Structure Support in TIA/EIA-136-A, June 9, 2000.

- TIA/EIA/IS-841, Network Based Enhancements for User Identity Module (UIM), August, 2000.

- TIA/EIA/IS-2000, Inter-Operability Specification (IOS) for CDMA 2000 Access Network Interfaces, 2000.

- TIA/EIA/J-STD-025, Lawfully Authorized Electronic Surveillance, 2000.

- TIA/EIA/J-STD-036, Wireless Enhanced Emergency Services, 2000. 